\title{
THERMAL INVERSIONS IDENTIFICATION THROUGH THE ANALYSIS OF THE VEGETATION INVERSIONS OCCURRED IN THE FOREST ECOSYSTEMS FROM THE EASTERN CARPATHIANS
}

\author{
Alexandru Ciutea ${ }^{1 *}$, Vasile Jitariu $^{1}$ \\ 1 "Alexandru Ioan Cuza" University of Iași, Romania \\ *Corresponding author: alex.ciutea@yahoo.com
}

Keywords: temperature inversion, old-growth forest, vegetation inversions, remote sensing.

\begin{abstract}
The earth's climate has a direct impact on the spatial distribution of the vegetation cover. Forests are one of the most prevalent ecosystems on earth. The forest's structure, if unaltered, can be an indicator of some climate patterns. This paper proposes an algorithm for identifying vegetation inversions within mountain forest ecosystems in the eastern Carpathians of Romania, using freely available GIS and remote sensing data. Air temperature has a direct impact on the spatial distribution of tree species. Therefore, temperature-inversion spatial patterns can be estimated.
\end{abstract}

\section{INTRODUCTION}

In order to have a correlation between the structure of a forest stand and the climate, it is imperative to take into consideration only the naturally occurring forests, thus excluding plantations. The largest areas of old-growth, or virgin forests from the temperate region of the European Union can be found in the Carpathian Mountains of Romania (Knorn et al., 2012). Some of these forests are found in our study area, but not all of them are identified and catalogued accordingly (Giurgiu et al, 2001). The mapping of the old-growth forests is not the main purpose of this paper, so in order to illustrate the proposed methodology we will take in consideration all forests within the mountainous region of our study area.

The study area is located in the Eastern Carpathian Mountains, in Romania (Fig. 1). More precisely, we selected the eastern and south-eastern regions of this mountain range, the external versants of the Northern, Central 
and Curvature subgroups, which area delineated with a thin red line on the attached map. The studied area is the mountainous region situated in the western half of the Siret river basin. This area was considered suitable for our study because of the very fragmented terrain, which is an important characteristic in our case, because the inaccessibility of the terrain can be correlated with the naturality of the forest stands (Biriș et al, 2005).

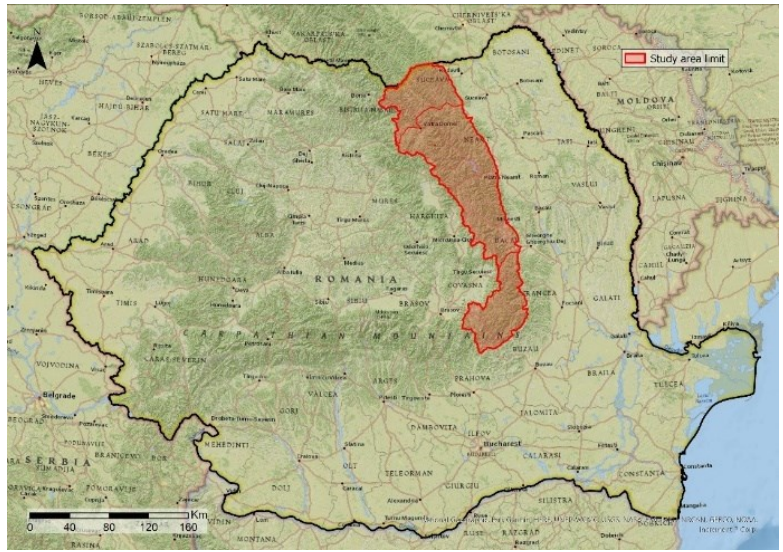

Figure 1. Location of the study area within Romania

In Romania, the thermal inversion phenomena were analyzed as a consequence of the changes induced by the topographic characteristics. In generally thermal inversion phenomena is associated with stable stratification conditions to the air in the low troposphere (Apăvăloae, 1987; , Ichim et al., 2014, Sfîcă 2015). Thermal inversions are caused by the seasonal and/or diurnal variation of the radiative heat balance, the fragmentation or depth of river valleys and the characteristics of the active surface (Apăvăloae et al., 1987; Ichim et al., 2014). Ichim et al., 2014, observed that thermal inversions in extra-Carpathian region have a frequency of almost $40 \% / y e a r$. In the mountain area, Sfică et al., 2019, observed six types of temperature stratifications which generates high frequency of thermal inversions that occurs in 60.2 days during year. Generally, the thermal inversions develop as a consequence of the thickness of continental cold air masses (Sfîcă et al., 2017), generally under 500-600 $\mathrm{m}$ with a frequency of $40 \%$ (Apostol et al. 2015, Sfícă, 2015). When the thermal inversions phenomena reach high frequencies generates thermal anomalies that creates specific patterns in air temperature distributions (Ichim et al., 2015), especially in depressions or deep rivers valleys (Sfîcă et al., 2019). Thermal inversions layer generate an warm belt, especially partial inversions that develop below $1200 \mathrm{~m}$ have an 
important impact on the vegetation and on the forestry ecosystem (Sfîcă et al., 2020).

The purpose of this paper is to illustrate an algorithm suitable for estimating the spatial location of the areas where vegetation inversions are visible, using remote sensing techniques, thus illustrating the areas where temperature inversions are a usual occurrence. We opted to create a methodology that could be applied at least on a national level.

\section{MATERIALS AND METHODS}

The methodology used for generating the polygons used as reference areas in the later analyses is illustrated bellow (Fig. 2). These polygons are actually representing the slopes within our study area. The purpose was to obtain a

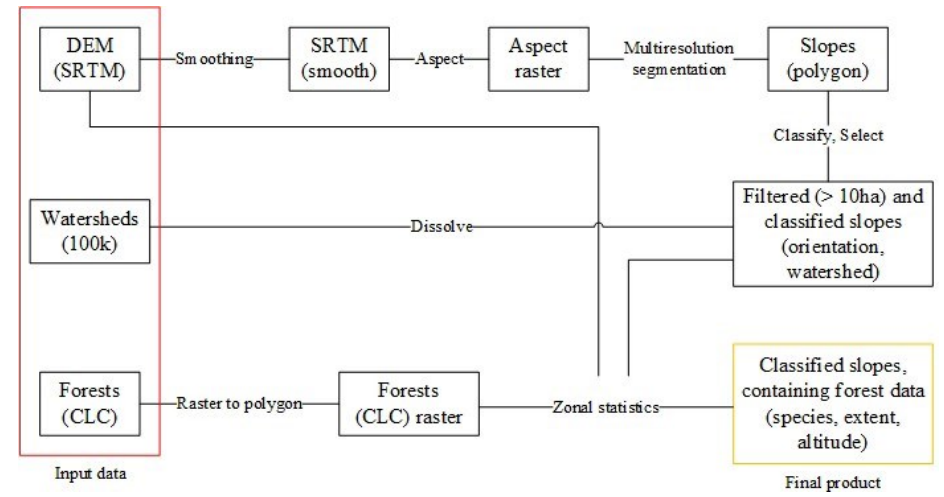

Figure 2. Generalized flowchart representing the process of creating the polygons used in the later analysis

detailed polygon vector layer containing information in its attribute table which could be later used to identify temperature inversion patterns by analyzing the vegetation (forest) inversions within the delineated mountain slopes. The information stored in the attribute table of the final product (layer) will contain statistics regarding the slope orientation and forest cover, such as the area occupied and the mean height of the CLC classified forest species within each of the polygon generated using the above illustrated algorithm. Freely available spatial data was used, mainly because we wanted to be able to easily adapt the methodology for other regions situated outside our study area. The SRTM digital elevation model (DEM) is available with a $30 \mathrm{~m}$ resolution for the Romanian territory (and many other countries). In our case we extracted the pixels intersecting our study area (Fig. 2). Watersheds extracted using topographic maps will be utilizes to correct some processing errors and also to 
more easily place the resulted polygons (Fig. 3).
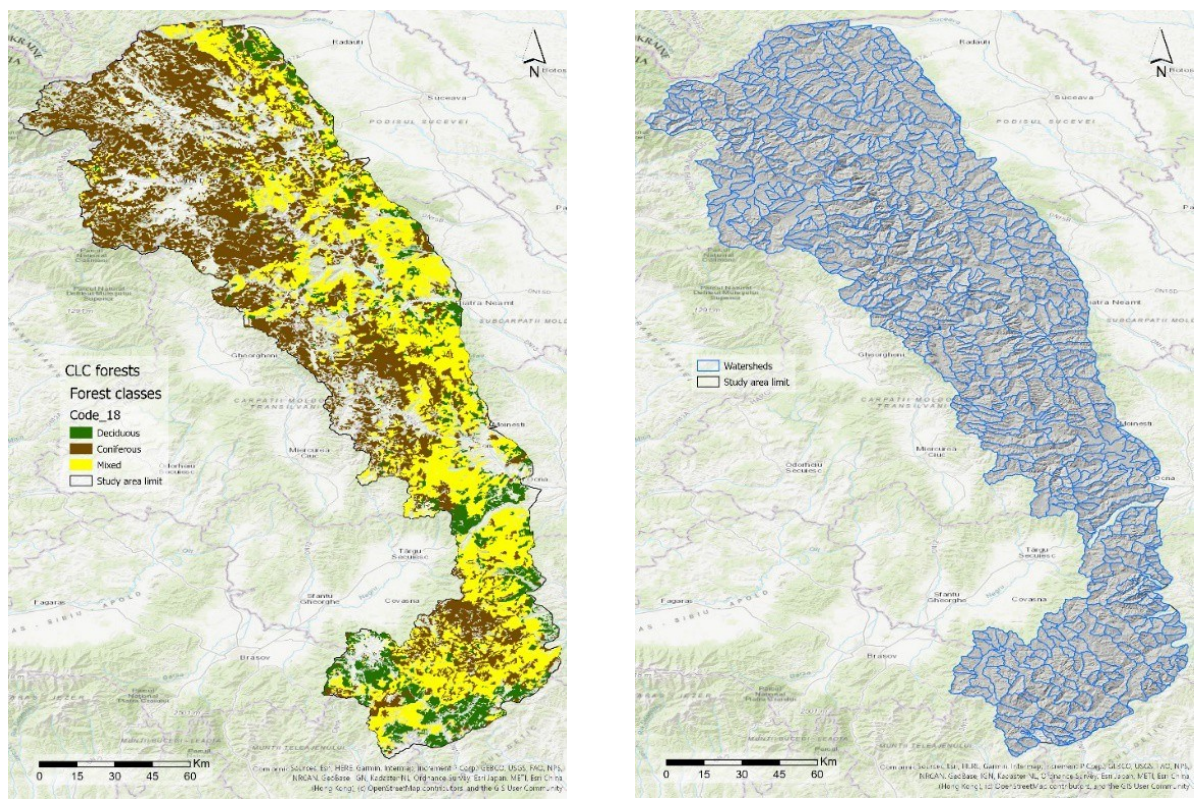

Figure 3. CLC derived forest cover (left) and the SRTM DEM (right) within our study area

The forest cover information was extracted using the latest Corine Land Cover (CLC) dataset, available for the year 2018 (Fig. 3). The Corine Land Cover products were initiated by the European Union (EU) and offers homogenous data for the EU territory because the cartographic database was created according to specific requirements and instructions (Pinilla, 2001; Land.copernicus.eu). Also, due to the complexity of this data set and the fact that it was conducted over several periods of time, CLC has also been used in complex studies on economic situations or pressures on protected areas (Ursu, 2017; Chelariu et al., 2019; Rusu, 2020).

Satellite remote sensing represents the optimal pathway for obtaining good results with low costs regarding forest monitoring (Pekkarinen, 2009) and over Romania studies aiming at afforestation and deforestation processes have been carried out by Popovici (2013), Ursu (2020). In this dataset, the forest types are classified in three generalized categories, according to the persistence of the canopy throughout the year.

Thus, there are deciduous, coniferous and mixed forests classes. Within our study area, according to the CLC dataset, there are a little over one million hectares of forest cover, coniferous species being the most common. The 
SRTM model was firstly processed using a low pass filter in order to smooth out the imperfections of the terrain. In our case, these imperfections are not only the result of the highly fragmented topographic surface, but also can appear due to radar waves reflecting in the forest's canopy, which covers most of our study area.

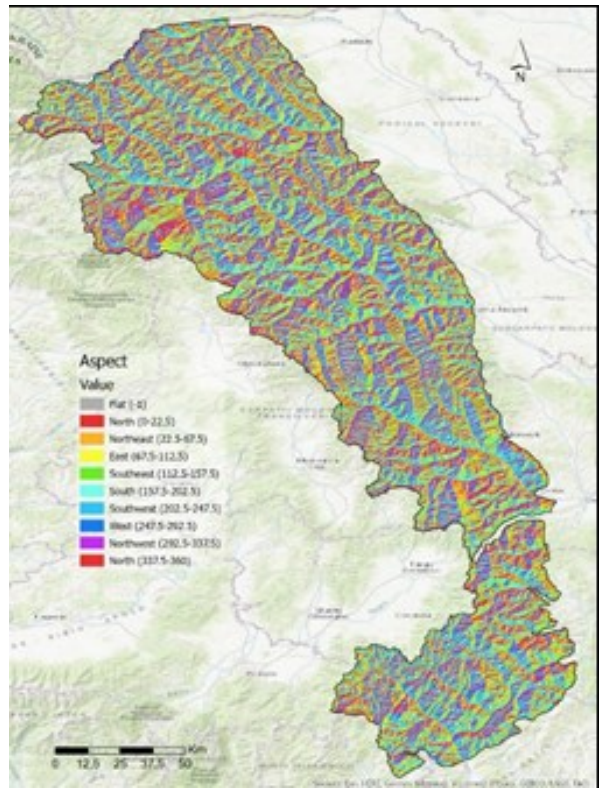

Figure 4. Slope orientation (aspect) raster

The raster representing the slope orientation was created using the "Aspect" tool found in the ArcGIS Pro software pack. The pixels have values within the range $0-360$. The raster was classified and nine orientation classes were obtained, including flat surfaces (Fig. 5). The flat surfaces were eliminated using the "Extract by attributes" tool. These areas are mostly specific to water bodies.

In order to generate the polygon layer representing the slopes, a segmentation algorithm was applied to the slope orientation raster. The "Multiresolution segmentation" (Deszo, Fekete, et. al, 2012) algorithm within the eCognition Developer software was used. The segmentation parameters were selected through an iterative process with the purpose of precisely delineating the mountain slopes within the above-mentioned watersheds. The "Compactness" parameter, which influences the homogeneity of the resulted objects (or polygons), was set to a higher value compared to the "Shape" parameter, which determines the influence of the pixel values (Navulur, 2006). 
Thus, the most clearly outlined slopes within our study area were delineated. As a result, 32.216 polygons were generated and were exported as a shapefile.

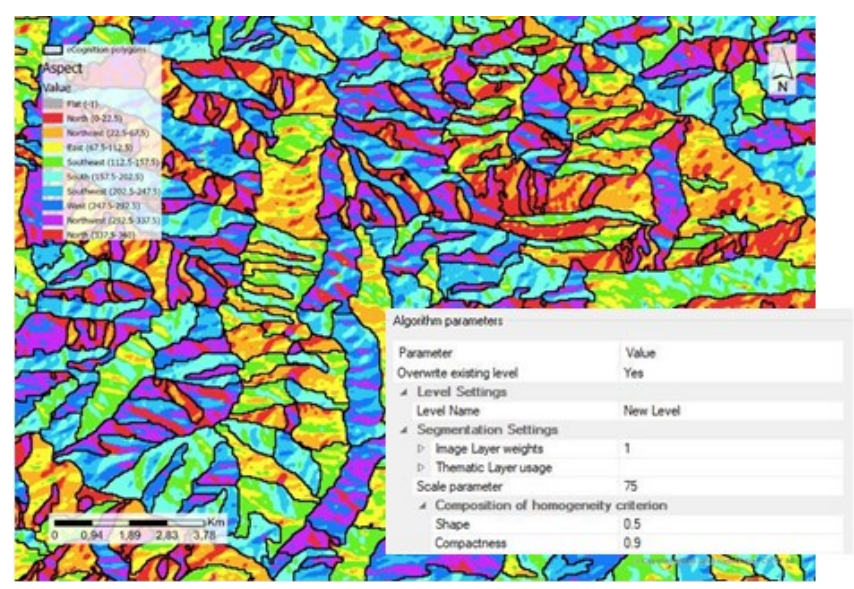

Figure 5. Detail within the study area, representing the aspect raster overlapping the polygons resulted from the segmentation process and the segmentation parameters

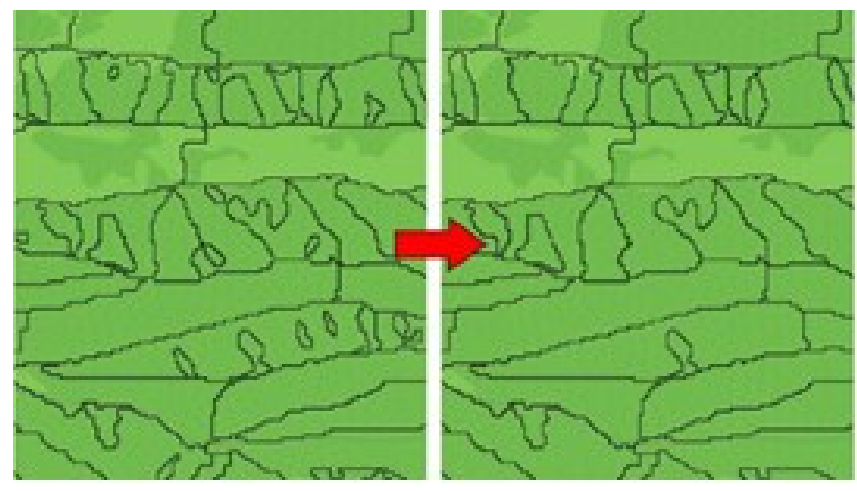

Figure 6. Polygons with an area smaller than 10ha

After the segmentation process, the polygons were filtered firstly by their area (Fig. 6). Only the objects with an area larger than 10 ha were kept. The smaller ones were merged with the neighboring polygons. It was considered that the smaller area slopes are insignificant for our analysis. The process was completed using the "Eliminate" tool found in ArcGIS Pro. After the merging process, the general orientation of the slopes was recalculated.

The general orientation of the resulted polygons was obtained using the "Zonal Statistics" tool with the "Mean" function applied. The aspect raster was 
utilized as input data. Eight orientation classes were generated, respectively north, north-east, north-west, west, east, south, south-east and south-west. Finally, neighboring polygons having the same orientation were merged taking into consideration their location within the 1:100.000 watersheds. After these processes the number of polygons within our study area decreased to 20.765 (Fig. 7).

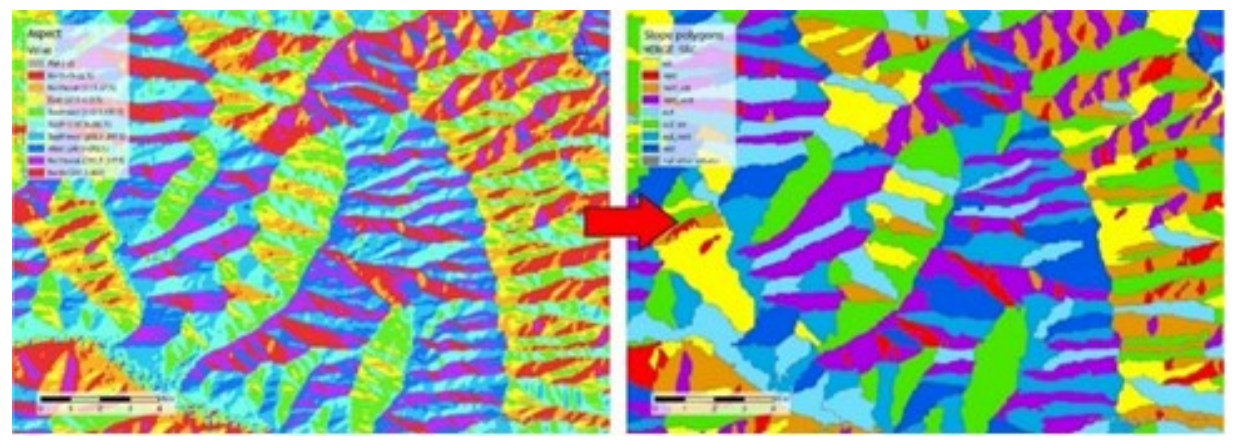

Figure 7. Polygon classification taking into account the general orientation of the slopes

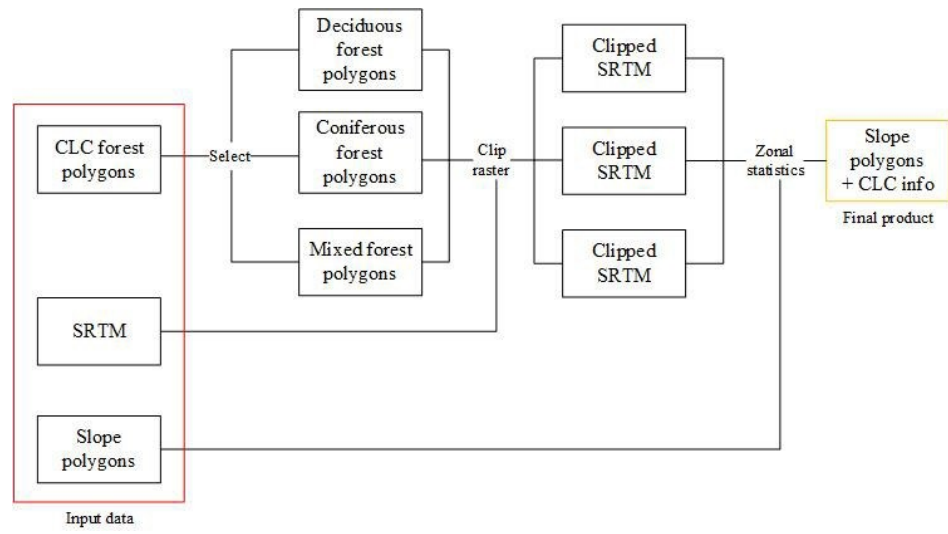

Figure 8. Flowchart illustrating the methodology used for the correlation of the slope polygons with the CLC forest data

In order to identify the vegetation inversion within a polygon (or slope polygon), it was necessary to consider the spatial distribution of the CLC forest classes taking into account the altitudinal values of the terrain. Thus, the altitudinal information available from the SRTM DEM was correlated with the forest classes extracted from the CLC dataset, for each one of the resulted polygons. Within each slope polygon, the mean height of the CLC forest 
classes and their weight were calculated and stored in the layer's attribute table. Therefore, the attribute table will contain eight new columns representing the area and the mean height of each forest class within each slope polygon. This data will be used to identify the polygons were vegetation inversions could exist, thus indicating the areas where temperature inversions could be frequent (Fig. 8).

To select the relevant polygons to be used in the further analyses, a series of conditions were applied. Slope polygons with an insignificant area (less than $10 \%$ covered by forest) were eliminated. Also, polygons where a certain CLC forest class is prevalent were not used in the analysis (Fig. 9). Only the polygons were the percentage of each forest class is at least $20 \%$ of the total area covered by forests within a polygon were taken into consideration.

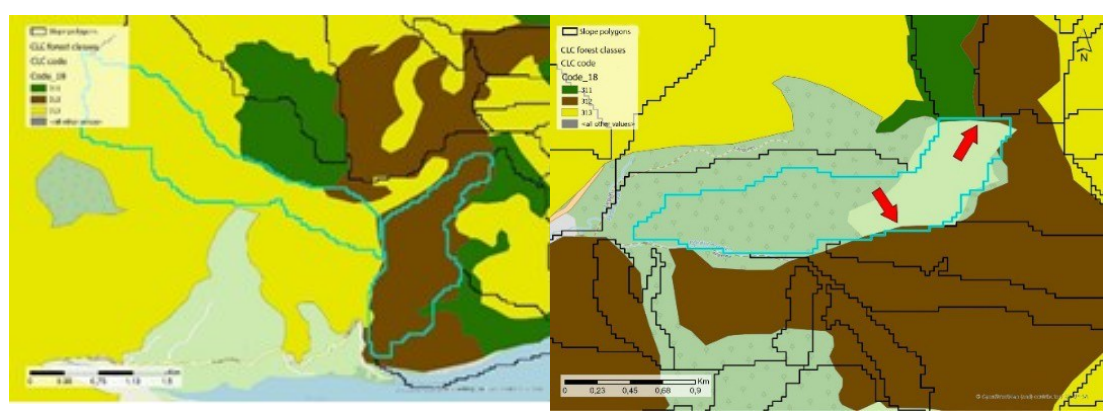

Figure 9. Examples of irrelevant polygons for the analysis

In order to classify a slope polygon as a are where a vegetation inversion could be present, three cases were considered. The most relevant scenario is the one where the mean altitude of the deciduous forest class is higher than the coniferous class. The other two situations are taking into consideration the "Mixed" forest class, where its mean altitude is lower than the "Deciduous" class or higher than the "Coniferous" class. If one of the mentioned scenarios is present, the slope polygon will be marked as a potential region were frequent temperature inversions are probable. In order to minimalize processing errors, this analysis will be applied for each of the above scenario, one at a time (Fig. $10)$.

Corine Land Cover is not the most accurate dataset for studying forest species spatial distribution. The inaccuracy arises especially because within the "Mixed" forest class, the percentage of the coniferous and deciduous species is unknown. Therefore, the result of our analysis would be more relevant if we would only use the coniferous and the deciduous forest classes of CLC. But because mixed forests are covering a large part of our study area, 
eliminating them from the analysis would materialize in having spatially inconsistent results. The compromise was to only consider two out of the three mentioned scenarios, thus excluding the mixed-deciduous comparison, as the percentage of the deciduous forests within our study area is relatively small. Finally, a number of 2326 polygons will be included in the analysis, which only represents about $7 \%$ of the initial number of segmented objects.

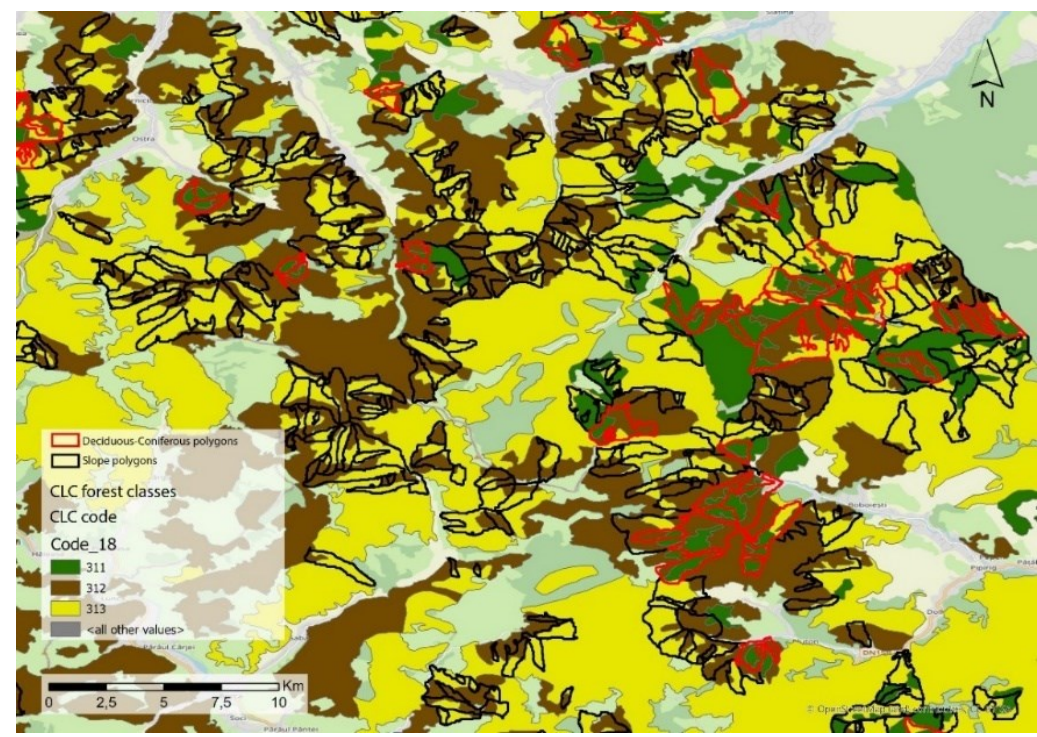

Figure 10. The polygons were split in order to identify potential temperature inversion regions

The "Select by Attributes" tool was used to select the polygons where the above-mentioned scenarios are met. For the "coniferous alt. < deciduous alt." scenario, a number of 250 polygons were identified. The "mixed alt. > coniferous alt." scenario generated a number of 1170 polygons. To highlight the areas were the inversions could be the most obvious, the selected polygons were classified taking into account the identified altitude difference between the coniferous forest class polygons and the deciduous, respectively mixed forest class polygons. This was done using the next formulas: "!MEAN conifere!/!MEAN foioase!*100"

and

"!MEAN_conifere!/!MEAN_amestec!*100". These formulas were applied to each one of the previously selected polygons and the results were stored within a new column of the layer's attribute table.

\section{RESULTS AND DISCUSSIONS}


A total of 1420 polygons were identified to meet the two previously detailed scenarios, representing the slopes where the mean altitude value of the area occupied by the "deciduous" or "mixed" CLC forest classes is higher than the mean altitude of the "coniferous" forest class. Figure 11 illustrates the results of the two analyses. The red and orange-colored areas are polygons where the altitude difference between the analyzed forest classes is highest. The numbers in the map's legend actually represent the similarity between the two altitudinal values, so the lower the number, the higher will be the altitude difference. Within these areas, the vegetation inversion and respectively the temperature-inversion phenomenon could have a higher probability of occurrence. We choose to firstly show the results of the two scenarios separately, to illustrate the importance of including the "Mixed" forest class in the analysis. Including mixed forests into the analysis resulted into a much better spatial coverage of the results, especially in the southern part of the study area, in the Vrancei Mountains region, where the terrain's mean altitude is lower.

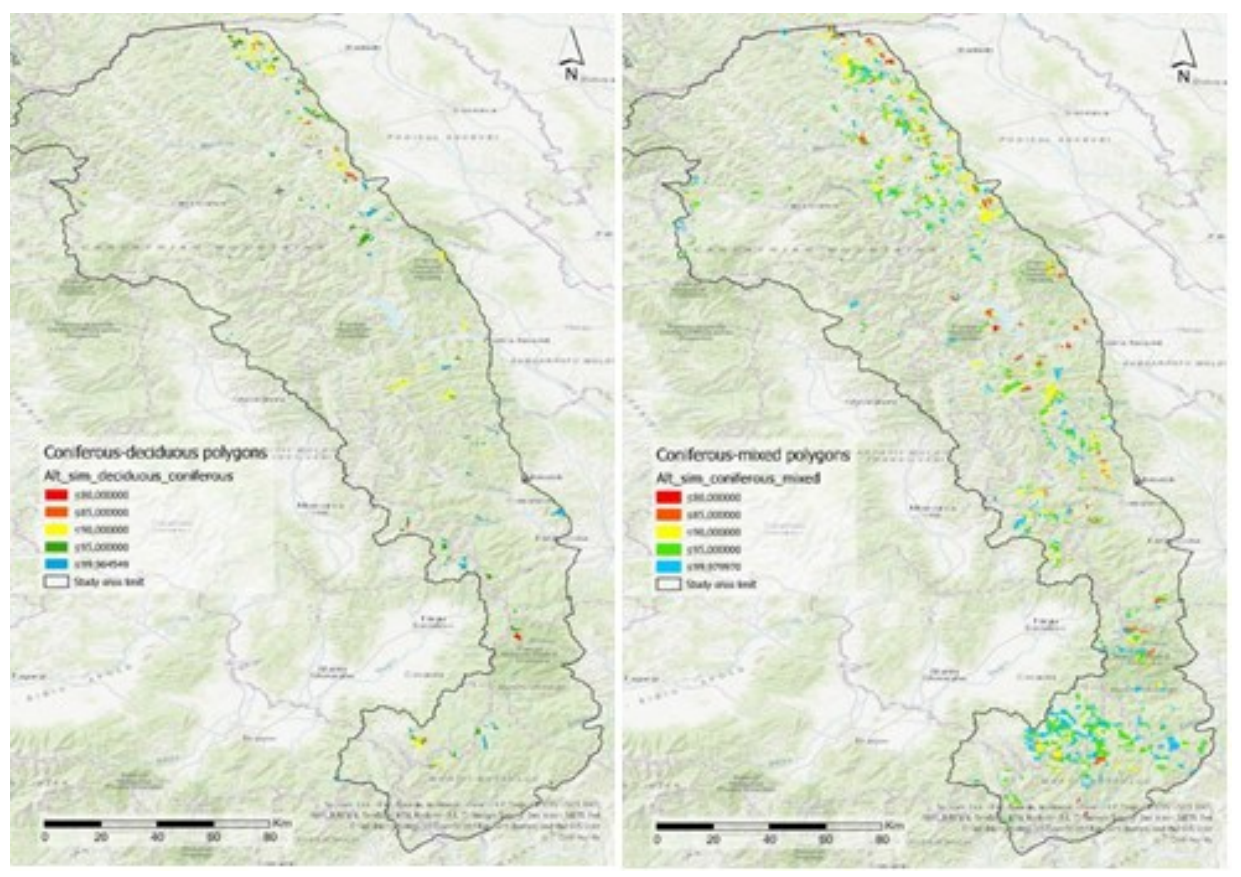

Figure 11. The results of the analysis of the coniferous-deciduous scenario (left) and the coniferous-mixed scenario (right)

Figure 12 illustrates the combined result of the previously detailed 
scenarios. The first thing that can be observed is the lack of information for the north-western part of the study area. This scarcity can be attributed to the limitations of the presented methodology in areas where the forest is homogenous in terms of species composition, or where the forest is missing completely, mainly because of the very high-altitude levels.

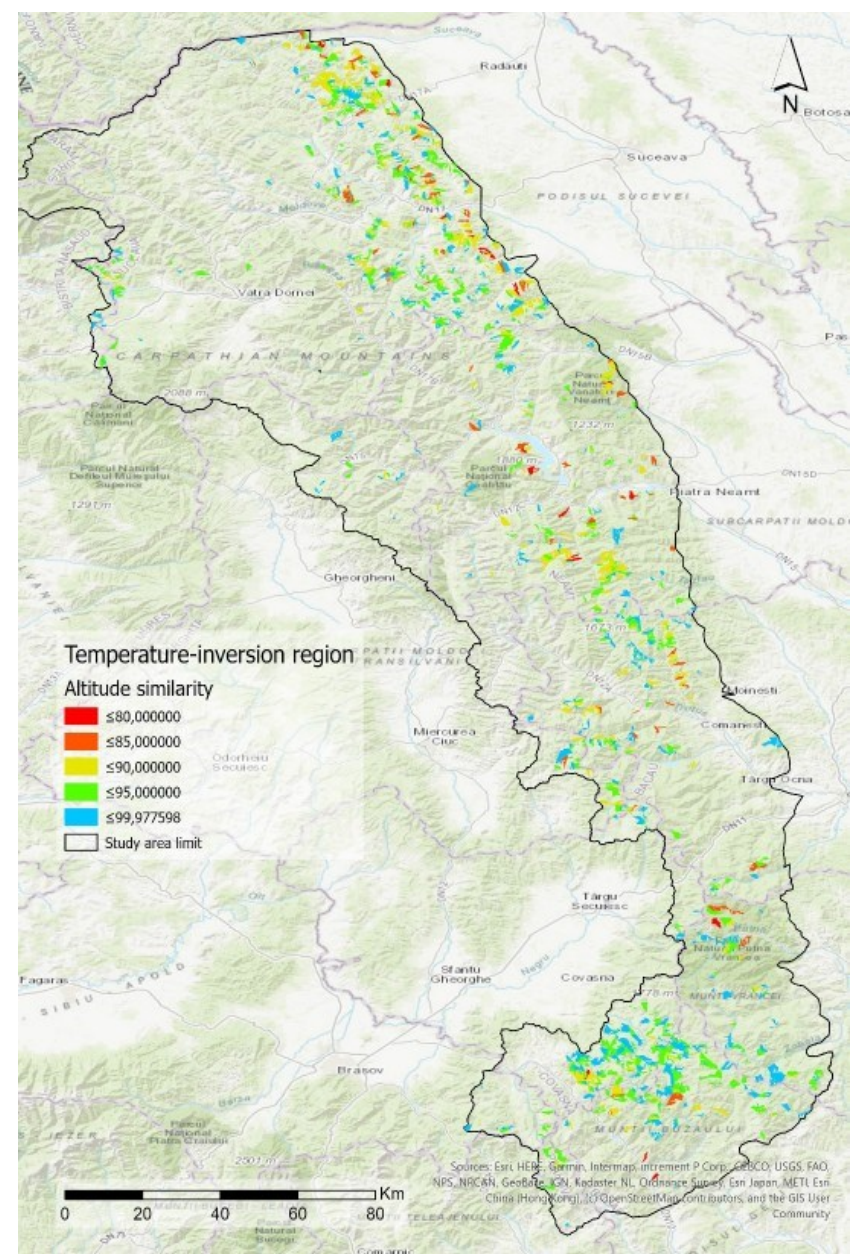

Figure 12. The combined result of the two scenarios

\section{CONCLUSIONS}

Certainly, the spatial extent of the temperature-inversion regions within our study area is broader compared to the previously illustrated results. The 
lack of information can be observed especially in the north-western part of the analyzed area. This is because the presented methodology estimates the spatial distribution of the temperature-inversion regions by observing vegetation inversions, more precisely inversions of the natural altitudinal distribution of the tree species found in mountain forest stands. Obviously, this algorithm implies the existence of a forest cover, but also of a heterogeneity of the forest's species composition. Therefore, this methodology is suitable for mountain areas where climate and terrain conditions are favorizing the development of heterogenous forest stands, where coniferous and deciduous species are both thriving.

The algorithm could be improved by using a more precise forest dataset. For example, by using very high resolution satellite or aerial images could lead to the creation of a much more precise mapping of the spatial distribution of tree species (Colomina et al, 2014). This way, the CLC's "mixed" forest class could be completely eliminated from the analysis, if we could identify the individual spatial location of the deciduous and coniferous trees within a forest stand. Also, high quality data could enable a much more accurate classification of tree species (Petrila et al, 2010). This would be useful because some tree species within the coniferous or the deciduous forest classes, are adapted to certain terrain conditions. Thus, by classifying individual tree species within the CLC's forest classes, the spatial extension of the results and the accuracy would be much higher.

\section{References:}

Apăvăloae, M., Pîrvulescu, I., Apostol, L. (1987), Caracteristici ale inversiunilor termice din Podișul Fălticeni. Lucrările "Seminarului geographic Dimitrie Cantemir", 8.

Apostol, L., Rusu C. (1998), Aspecte privind temperatura aerului în Masivul Rarău, Lucrările Seminarului Geografic „Dimitrie Cantemir”, nr. 9

Apostol, L., Bărcăcianu, F., Ichim, P., \& Sfîcă, L., (2015). The thermal inversion phenomena on ground level and in the free atmosphere in the first $3000 \mathrm{~m}$ above Moldova, Romania. Advances in Environmental Sciences, 7(2), 196-204,

Apostol, L. (2016), Clima Subcarpaţilor Moldovei, Editura Universităţii Suceava, Suceava.

Barbu, I., Barbu, C., Curcă, M., Ichim, V. (2016) Adaptarea pădurilor României la schimbările climatice, Ed. Silvică, București. [link]

Biriș-Iovu, A., Veen, P. (2005): Virgin forests in Romania. Inventory and strategy for sustainable management and protection of virgin forests in Romania. In Document ICAS, Bucharest. 
Cenuşă, R. (1994), Caracteristici ale inversiunilor termice în zonele montane Călimani şi Rarău, Analele Universităţii „Ştefan cel Mare” Suceava - Secţia Silvicultură, vol. I.

Cenușă, R. (1996), Probleme de ecologie forestieră. Teoria fazelor de dezvoltare. Aplicații la molidișuri naturale din Bucovina, Universitatea „Ștefan cel Mare“, Suceava.

Chelariu, O., A., Ursu, A., (2019) From industrial to commercial, an Eastern European phenomenon. Case study: Moldova, Romania, 19th SGEM International Multidisciplinary Scientific GeoConference EXPO, DOI: $10.5593 /$ sgem 2019/2.2/S11.104

Colomina, I., Molina, P. (2014), Unmanned aerial systems for photogrammetry and remote sensing: A review. J. Photogramm. Remote Sens, 7, 9632-9654, https://doi.org/10.1016/j.isprsjprs.2014.02.013

Corine Land Cover - Copernicus Land Monitoring Service ( https://land.copernicus.eu/pan-european/corine-land-cover/ )

Dandois, J. P., and E. C. Ellis. 2010. Remote Sensing of Vegetation Structure Using Computer Vision, Remote Sensing 2 (4): 1157-1176. https://doi.org/10.3390/rs2041157

Dezso, B., Fekete, I.; Gera, D., Giachetta, R.; László, I., Benczúr, A., Dezs, B., Fekete, I., Gera, D., Giachetta, R. et al. (2012), Object-based image analysis in remote sensing applications using various segmentation techniques. Ann. Univ. Sci. Budapest. Sect. Comp, 37, 103-120, [link]

Gallego, J. (2000), Comparing CORINE Land Cover with a More Detailed Database in Arezzo (Italy)

Giurgiu V., Doniță N., Bândiu C., Radu S., Cenușă R., Dissescu R., Stoiculescu C., Biriș- Iovu, A. (2001), Pădurile virgine din Romania, asbl Foret wallone, Bruxelles

Ichim, P., Apostol, L., Sfîcă, L., Kadhim-Abid, A.L., Istrate, V., (2014), Frequency of thermal inversions between Siret and Prut rivers in 2013, Present Environment and Sustainable Development, 8 (2): 267-284, doi: https://doi.org/10.2478/pesd-2014-0040

Ichim, P., Apostol, L., Sfîcă, L., Kadhim-Abid, A-L. (2015) AIR TEMPERATURE ANOMALIES BETWEEN THE RIVERS SIRET AND PRUT IN ROMANIA, LUCRĂRILE SEMINARULUI GEOGRAFIC “DIMITRIE CANTEMIR" NR. 40, 2015

Lisein, J., Michez, A., Claessens, H., Lejeune, P. (2015), Discrimination of deciduous tree species from time series of unmanned aerial system imagery, PLOS ONE 2015, San Francisco, California, https://doi.org/10.1371/journal.pone.0141006

Navulur, K. (2006) Multispectral Image Analysis Using the Object Oriented Paradigm, USA

Pekkarinen, A., Reithmaier, L., Strobl, P. (2009), Pan-European forest/non-forest mapping with Landsat ETM+ and CORINE Land Cover 2000 data, https://doi.org/10.1016/j.isprsjprs.2008.09.004 
Petrila, M., Apostol, B., Gancz, V., Lorent, A. (2010), Aplicații ale tehnologiilor geomatice în silvicultură, Ed. Silvică, București.

Popovici, E-A., Balteanu, D., Kucsicsa, G. (2013), Assesment of changes in land-use and land-cover pattern in Romania using Corine Land Cover database, Carpathian Journal of Earth and Environmental Sciences, November 2013, Vol. 8, No. 4, p. $195-208$

Rusu, A., Ursu, A., Stoleriu, C., Groza, O., Niacsu, L., Sfica, L., Minea, I., Stoleriu, O. M., (2020) Structural Changes in the Romanian Economy Reflected through Corine Land Cover Datasets, Remote Sensing 12(8):1323 DOI: $10.3390 / \mathrm{rs} 12081323$

Sfîcă, L., (2015), Clima Culoarului Siretului şi a regiunilor limitrofe, Editura Universității "AlexandruIoanCuza" din Iași.

Sfícă, L., Croitoru A-E., Iordache, I., Ciupertea F-A. (2017), Synoptic conditions generating heat waves and warm spells in Romania, Atmosphere, 8 (3), 50; doi: https://doi.org/10.3390/atmos 8030050

Sfîcă, L., Nicuriuc, I., Niță, A.(2019), Boundary Layer Temperature Stratification as Result of Atmospheric Circulation Within the Western Side of Brașov Depression, 2019 "Air and Water - Components ofthe Environment" Conference Proceedings, Cluj-Napoca, Romania, p. 53-64, DOI: https://doi.org/10.24193/AWC2019_06

Sfîcă, L., Husariu, D., Ichim, P., Nita, A.I. (2020) Air Temperature Stratification Near the Ground in Relation with Atmospheric Circulation Within the Siret Corridor. 2020 "Air and Water - Components of the Environment" Conference Proceedings, Cluj-Napoca, Romania, p. 117-126, DOI: https://doi.org/10.24193/AWC2020 11

Ursu, A., Jitariu, V., Ciutea, A., (2017) Estimating the impact of Human Activities on the environment in Moldova Region, Present Environment and Sustainable Development 11(2) DOI:10.1515/pesd-2017-0031

Ursu, A., Stoleriu, C-C., Ion, C., Jitariu, V., Enea, A., (2020), Romanian Natura 2000 network: Evaluation of the threats and pressures through the Corine Land Cover dataset, Remote Sens.2020, 12(13), 2075; https://doi.org/10.3390/rs12132075

* * * (2016), GeoVille Environmental Services Sàrl (GeoVille, LUX), Development of $E O$ derived information services for EEA.

(C) 2020 by the authors. Licensee UAIC, Iasi, Romania. This article is an open access article distributed under the terms and conditions of the Creative Commons Attribution (CC BY-NC-ND) license (https://creativecommons.org/licenses/by-nc-nd/4.0). 